\title{
Evaluating Defoaming Agents for the Stripping Columns at the In-Tank Precipitation Facility
}

by

J. F. McGlynn

Westinghouse Savannah River Company

Savannah River Site

Aiken, South Carolina 29808

\section{RECEIVED \\ SEP 16 1998 \\ OSTI}

DOE Contract No. DE-AC09-89SR18035

This paper was prepared in connection with work done under the above contract number with the U. S. Department of Energy. By acceptance of this paper, the publisher and/or recipient acknowledges the U. S. Government's right to retain a nonexclusive, royalty-free license in and to any copyright covering this paper, along with the right to reproduce and to authorize others to reproduce all or part of the copyrighted paper. 


\section{DISCLAIMER}

This report was prepared as an account of work sponsored by an agency of the United States Government. Neither the United States Government nor any agency thereof, nor any of their employees, makes any warranty, express or implied, or assumes any legal liability or responsibility for the accuracy, completeness, or usefulness of any information, apparatus, product, or process disclosed, or represents that its use would not infringe privately owned rights. Reference herein to any specific commercial product, process, or service by trade name, trademark, manufacturer, or otherwise does not necessarily constitute or imply its endorsement, recommendation, or favoring by the United States Government or any agency thereof. The views and opinions of authors expressed herein do not necessarily state or reflect those of the United States Government or any agency thereof.

This report has been reproduced directly from the best available copy.

Available to DOE and DOE contractors from the Office of Scientific and Technical Information, P.O. Box 62, Oak Ridge, TN 37831; prices available from (615) 576-8401.

Available to the public from the National Technical Information Service, U.S. Department of Commerce, 5285 Port Royal Road, Springfield, VA 22161. 


\section{DISCLAIMER}

Portions of this document may be illegible in electronic image products. Images are produced from the best available original document. 
Westinghouse Savannah River Company Savannah River Technology Center

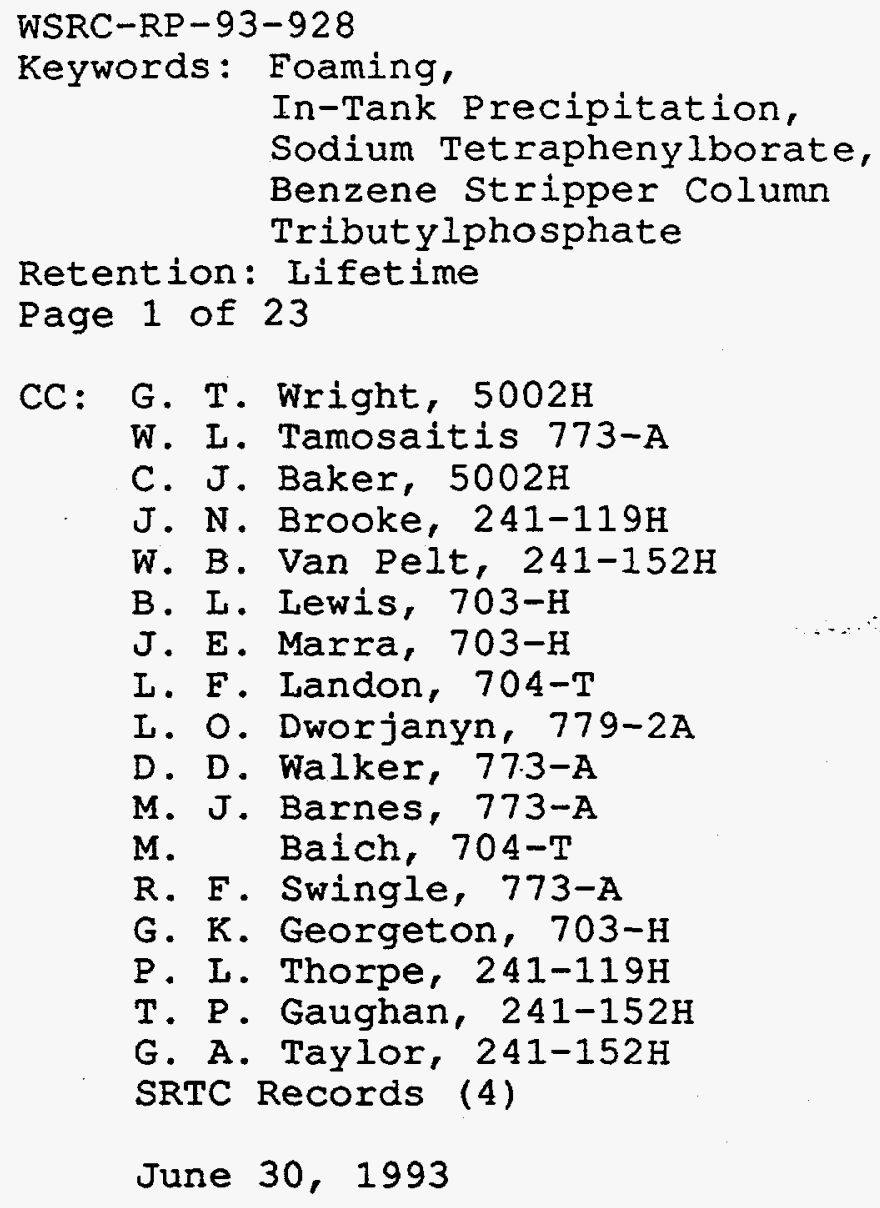

To: S. D. Fink, 773-A

From: J. F. MCGlynn, 773-A G.T.Miglapen

\section{EVALUATING DEFOAMING AGENTS FOR THE STRIPPING COLUMNS AT THE IN-TANK RRECIPITATION FACIIITY (U)}

\section{SUMMARY}

During initial testing of the stripper columns in the In-Tank Precipitation facility, differential pressures in excess of design specifications have been observed. The root cause of the excessive pressure drops has been attributed to foaming of the simulant salt solution used for acceptance testing. An experimental program was completed to confirm foaming as a cause, to identify and evaluate chemical additives to inhibit foaming, and to provide operating guidance for these defoaming agents in 
support of facility acceptance testing, vendor pilot scale testing, and normal operations. These tests indicate that:

- Tributylphosphate, at concentrations no greater than $150 \mathrm{ppm}$ in the filtrate, is the defoaming agent recommended for use in the In-Tank Precipitation benzene stripper columns.

- Sparging tests show that tributylphospate up to a concentration of $300 \mathrm{ppm}$ does not adversely affect benzene removal.

- The tributylphosphate can be cleaned from the temporary feed tank at ITP using deionized water at 5\% of the tank volume.

- Benzene can be added to the temporary feed tank at ITP using the benzene injection port within a 4-6 hour period to obtain a saturated solution.

\section{INTRODUCTION}

The In-Tank Precipitation (ITP) process will concentrate the Tank 48 contents to approximately 10 wt. $\frac{q}{8}$ tetraphenylborate solids by filtration. The filtrate produced during the process flows to the ITP stripping columns where the soluble benzene is removed from the solution. It has been observed that a large pressure differential occurs across the column packing when the filtrate is processed in the column. One potential explanation for the pressure differential is that the filtrate is foaming in the column. Small scale stripping tests have verified that the salt solution foams. 1,8

Waste Management requested assistance from SRTC in solving the foaming problem through technical task requests HLE-TTR-93013A/B (Benzene Stripper Performance Evaluation) and HLE-TTR-93044 (Kinetics of Benzene and Dissolution). Various tests were completed to determine an effective defoaming agent for use in the stripping columns. This document discusses the tests and the conclusions.

The conclusions from this testing were used as information in developing a test plan at the vendor's (Koch Engineering Company) facility. Koch Engineering performed several tests on an eight inch diameter column at their testing facility. These tests verified that tributylphosphate inhibits foaming of the salt solution. 
WSRC-RP $-93-928$

Page 3 of 23

\section{EXPERIMENTAL}

The study consisted of several phases:

(1) scouting tests to determine the impact various defoaming reagents have on the foaming behavior of simulated ITP salt solutions,

(2) simulation of ITP column performance in the presence of selected reagents,

(3) estimation of the effect of selected defoaming agents on volatility of benzene from the simulated salt solutions,

(4) qualitative evaluation of the wetting behavior of selected defoaming agents on stainless steel,

(5) simulation of the ITP benzene injection system for the ITP stripper column acceptance test, and

(6) testing the efficiency of tributylphosphate (the optimal defoaming reagent) removal from process equipment.

Salt Solution Formulation

Filtrate was made simulating the actual salt expected in the ITP facility. The filtrate was obtained from two sources: (1) a simulated salt solution was made using a lab procedure (see Table 1), and (2) filtrate supplied by $M$. Morrissey from the . Experimental Laboratory Filter apparatus at TNX (see Table 2).

\section{Defoaming Agent Tests}

A standardized test device was used to determine the ability of various defoaming agents to reduce the foam height and shorten the collapse time of the salt solution. These tests identified defoaming agents to test in the small scale stripping column. Several defoaming agents were identified for testing by J. P. Bibler ${ }^{2}$ and C. A. Langton: Gafac ${ }^{\circledR}$ RA-600 surfactant; n-tributylphosphate, Pegol ${ }^{\circledR} \mathrm{L}-62$, Triton ${ }^{\circledR} \mathrm{x}-100$ surfactant, surfynol 104E, Dow Corning ${ }^{\circledR}$ antifoam 544, and Triton ${ }^{\circledR} \mathrm{X}-114$ surfactant. Surfynol $104 \mathrm{E}$ and Dow Corning ${ }^{\circledR}$ antifoam 544 have been proposed for use in the Defense waste Processing Facility.

The experimental unit consisted of a $500 \mathrm{~mL}$ graduated cylinder with a sparge tube placed at the center of the cylinder

- approximately one half inch from the bottom (see Figure 1). The sparge tube is a standard stores stocked item with a coarse frit of pore size $40-60 \mu \mathrm{m}$. The fritted portion at the bottom of the tube has a cylindrical shape with length of approximately 21 $\mathrm{mm}$ and a diameter of $11 \mathrm{~mm}$. Each sparge tube has a varying amount of actual sparging area ( $i . e .$, the amount of bubbles produced varies slightly). 
The $500 \mathrm{~mL}$ graduated cylinder was filled with $200 \mathrm{~mL}$ of salt solution. The initial level of the solution with the sparge tube immersed was marked. Nitrogen was supplied to the sparge tube at $0.6 \mathrm{~L} / \mathrm{min}$ causing the solution to foam (flow rate based on a previous test performed by D.D. Walker 4 ). The stable height of the foam was marked. The sparge tube was removed and the collapse time of the foam measured. Defoaming agent was added in small increments. The test was repeated after each addition to determine the effect of defoaming agent concentration on foam height and stability.

\section{Simulating Foaming of the Decontaminated Stripping Column}

These tests were performed to establish conditions which cause foaming, and to evaluate the ability of selected foaming agents to inhibit the foaming. The stripping columns at ITP have nitrogen and salt solution flowing countercurrently. The experimental stripper is intended as a small scale version of the Decontaminated Salt Solution benzene stripper column in the ITP process. The experimental column was designed on the following assumptions.

- The gas and liquid flow rates are scaled by the same factor and are based on the cross-sectional area of the column (SCFM of nitrogen/ft ${ }^{2}$ and GPM of filtrate/ft ${ }^{2}$ ).

- The height and diameter of the column packing are scaled :by the same factor $(15: 1)$.

- The experimental column packing is stainless steel sponge material. It is a random packing whereas the ITP column packing is a structured stainless steel packing (Koch $1 Y$ Flexipak ${ }^{\circledR}$ ).

- Various packing materials were tested in the column before choosing the stainless steel sponge (i.e., glass beads, Pro-Pak protruded metal distillation packing, and stainless steel sponge).

A $680 \mathrm{~mL}$ reservoir was used as both the feed and hold tank, unlike the ITP facility which has separate feed and hold tanks. A centrifugal pump supplied the column with the desired filtrate flow rate. Nitrogen was supplied to the column at the calculated flow rate using the laboratory nitrogen supply. Figure 2 and Table 3 detail the equipment setup and operating parameters. 
The system was operated at a condition which produced foaming in the column. In the small scale column, it has been observed that foaming increases when the nitrogen flow rate is increased. Therefore filtrate was supplied at its maximum flow rate, and nitrogen was increased gradually until foaming occurred in the column.

After determining the conditions of foaming in the experimental column, the salt solution was spiked with defoaming agent in $25 \mathrm{ppm}$ increments to determine the concentration at which the defoaming agent controls foaming in the column.

\section{Effect of Defoaming Agents on Benzene Removal}

The proposed Late Wash Facility will use sparging to remove the benzene in solution. Previous tests were performed in 1992 to determine if surfynol $104 \mathrm{E}$ inhibits benzene removal.7 Additional testing was done as part of this study using tributylphosphate. The results from these tests were compared to determine the effects of defoaming agent on the removal of benzene.

The sparging apparatus is a small scale version of the sparge tank in the proposed Late Wash Facility (see Figure 3 for details). The nitrogen sparge rate for the tests was 0.62 SCFM/ft ${ }^{2}$ (this is the proposed design rate for the Late Wash facility).

The sparge tank was filled with $691 \mathrm{~mL}$ of salt solution premixed with a specified amount of benzene and defoaming agent. The solution was sampled prior to any sparging. Nitrogen was sparged through the solution at the specified rate. Samples were taken every two minutes for the first ten minutes, followed by two additional samples at ten minute intervals. Several tests were run with different concentrations of the defoaming agent to determine its effect on benzene removal.

\section{Simulation of Benzene Addition to the ITP Test Facility}

To effectively test the ITP benzene strippers, it is necessary to achieve a specified concentration of benzene near the solubility limit in the feed to the stripping column. At the ITP facility it is planned to recirculate the salt solution through the feed tank and use an injection port to add the benzene. The benzene addition apparatus of this study is a small scale version of the ITP temporary facility feed tank. The test simulated the addition of benzene through an injection port in the piping system. 
WSRC-RP-93-928

Page 6 of 23

The apparatus (see Figure 4 for details) was designed on the following assumptions.

- The reservoir was scaled to approximately 1:5,000 of the existing ITP design.

- The reservoir contained $66.7 \%$ liquid by volume and $33.3 \%$ vapor by volume.

- The benzene was added at the rate of $0.1 \mathrm{~mL}$ every 10 minutes over a four hour period to simulate the injection profile proposed for the facility during benzene acceptance testing.

A $5785 \mathrm{~mL}$ reservoir was filled with $3856 \mathrm{~mL}$ of salt solution. A total of $2.5 \mathrm{~mL}$ of benzene was added to the salt solution through an in-line injection port. The solution was recirculated continuously for six hours at one gallon per minute using a micro pump. A sample of the reservoir contents was taken each hour.

\section{Surface Wetting Tests}

Wetting tests were done to determine if the defoaming agents would spread over a stainless steel coupon in a salt free environment and when the coupon is coated with salt solution. A drop of tributylphosphate and a drop of surfynol $104 \mathrm{E}$ were added onto stainless steel coupons with and without a coating of salt solution to determine if the defoaming agents would spread across the surface.

\section{Residual Cleaning Tests}

Tests were performed to determine an efficient cleaning method of tributylphosphate contaminated equipment. A $500 \mathrm{~mL}$ graduated cylinder was filled with $200 \mathrm{~mL}$ of salt solution and sparged with nitrogen to obtain an original foam height.

Tributylphosphate was added to the solution, and sparged with nitrogen to determine the effect of the defoaming agent on foam height. The graduated cylinder was rinsed with a small volume of deionized water and removed with a pipette. Clean salt solution was added to the cylinder and sparged with nitrogen to determine if the solution foamed. If it did not foam, then the cleaning was not sufficient to remove the tributylphosphate. Various quantities of deionized water were used to rinse the cylinder to determine the appropriate amount needed to clean the glassware. 
WSRC-RP-93-928

Page 7 of 23

\section{RESULTS AND OBSERVATIONS}

\section{Analytical support}

The benzene concentrations reported in this document were provided by the DWPT analytical laboratory at TNX. Organic and inorganic chemical concentrations were provided by both the DWPT laboratory and ADS laboratory in 773-A.

\section{Defoaming Agent Tests}

J. P. Bibler researched a variety of defoaming agents available for testing. 2 This study eliminated ineffective defoamers, and identified defoamers which inhibit the salt solution foaming. Tributylphosphate, $\operatorname{Gafac}^{\circledR} \mathrm{RA}-600$, and surfynol $104 \mathrm{E}$ were most effective in eliminating foaming (see Table 4 and Figure 5). The remaining agents proved relatively ineffective. It was determined to test surfynol $104 \mathrm{E}$ and tributylphosphate.

\section{Simulating Foaming of the Decontaminated stripping Column}

After identifying the defoaming agents which inhibit foaming, an experimental stripping column was installed. Various random packing materials were placed in the column to determine the material which provided reproducible foaming. The following packing materials were tested: glass beads, Pro-Pak protruded metal distillation packing, and stainless steel sponge padding. The tests revealed that the stainless steel sponge padding offered the best foaming reproducibility.

Tributylphosphate and surfynol 104E were tested in the small scale column to determine if they were effective in eliminating foaming in packed columns. Although Gafac ${ }^{\circledR}$ RA-600 successfully inhibited foam formation, it was not tested. Gafac ${ }^{\circledR}$ RA-600 created a residual foam layer which would not collapse rapidly. The foam layer was approximately $25 \mathrm{~mm}$ in height and was a white froth. The effectiveness of tributylphosphate and its expected compatibility with saltstone allowed the elimination of Gafac ${ }^{\circledR}$ RA600 from further testing. Defoaming agent was added to the salt solution in $25 \mathrm{ppm}$ increments. The solution was stirred in a flask for approximately one-half hour. The solution was added to the small scale stripping column and observed visually for foaming.

From these tests tributylphosphate is recommended for use in the process at a concentration equal to or less than $150 \mathrm{ppm}$. The testing illustrated that $75 \mathrm{ppm}$ was the initial concentration that controlled foaming at the baseline conditions. At a concentration of $150 \mathrm{ppm}$ the system did not foam at the baseline conditions as well as conditions of higher nitrogen flow rates. In several tests solids were observed in solution at a tributylphosphate concentration of approximately $100 \mathrm{ppm}$. 
WSRC-RP $-93-928$

Page 8 of 23

Surfynol $104 \mathrm{E}$ did not control foaming at or above the baseline conditions. The surfynol $104 \mathrm{E}$ was added in increments up to a concentration of $550 \mathrm{ppm}$. At all concentrations this defoaming agent failed to inhibit foaming. Solids began to form at a concentration of approximately $100 \mathrm{ppm}$.

Effect of Defoaming Agents on Benzene Removal

After demonstrating that tributylphosphate eliminates foaming in the stripping column, its effect on benzene removal from the salt solution was tested. The sparging apparatus was used for this testing. Salt solution spiked with benzene and with tributylphosphate concentrations of $0 \mathrm{ppm}, 150 \mathrm{ppm}$, and $300 \mathrm{ppm}$ was sparged with nitrogen at a flow rate of $0.6 \mathrm{~L} / \mathrm{min}$.

From the results (see Table 5 and Figure 6 ) it was determined that the defoaming agent tributylphosphate did not adversely affect the benzene removal. After 10 minutes of sparging the benzene concentration was less than 1 ppm for all three tributylphosphate concentrations.

\section{Simulation of Benzene Addition to the ITP Test Facility}

An experiment simulating benzene addition to the test facility was completed. The purpose of this test was to determine if a benzene concentration near the solubility limit could be achieved in the temporary facility tank. The results (see Table 6 and Figure 7) indicate that the facility should be able to achieve the desired liquid phase concentration of benzene by recirculating the salt solution between four to six hours.

\section{Surface Wetting Tests}

Wetting tests were completed to compare if a drop of tributylphosphate and a drop of surfynol $104 \mathrm{E}$ would spread across the surface of a stainless steel coupon. Drops of each were placed on a coupon and allowed to spread for five minutes before observing. Tributylphosphate covered the most surface area in a salt free environment (see Figure 8). The coupons were placed in salt solution overnight. A drop of tributylphosphate and a drop of surfynol $104 \mathrm{E}$ were placed on the salt covered coupons. The amount of area covered by the surfynol $104 \mathrm{E}$ was slightly greater than the area covered by tributylphosphate.

\section{Residual Cleaning Tests}

- A cleaning test was completed to determine how much deionized water is needed to clean the surface of the tank after the addition of tributylphosphate. Various rinsings were done to determine the volume percent needed to clean the tributylphosphate from the walls of the cylinder. The cleaning test results indicated that deionized water at $5 \%$ the tank volume would be sufficient for cleaning (see Table 7). 
WSRC-RP-93-928

Page 9 of 23

\section{CONCIUSIONS}

An experimental program was conducted to identify an effective defoaming agent for the ITP stripping columns. From this program the following results were determined:

- Tributylphosphate is the defoaming agent recommended for use in the ITP stripping columns at a concentration of no more than $150 \mathrm{ppm}$.

- Tributylphosphate does not adversely affect benzene removal.

- The tributylphosphate can be cleaned from the temporary feed tank at ITP using deionized water at 5\% of the tank volume.

- Benzene can be added to the temporary feed tank at ITP using the benzene injection port within a $4-6$ hour period to obtain a saturated solution.

\section{QUALITY ASSURANCE}

All laboratory procedures, data, and observations discussed in this report are recorded in laboratory notebook WSRC-NB-92-145. The following documents defined this experimental program:

Technical task requests:

- HLE-TTR-93013A/B

- HLE-TTR-93044

Program plans:

- SRT-LWP-93-035

- SRT-LWP-93-036

- SRT-LWP-93-037

- SRT-LWP-93-041
"Benzene Stripper Performance Evaluation"

"Kinetics of Benzene Dissolution"

"Program Plan to Evaluate and Compare how Various Surfactants Effect Foaming of a Simulated Decontaminated Salt Solution which Feeds the In-tank Precipitation Stripping Columns"

"Program Plan to Evaluate the Characteristics of a Simulated Salt Solution in the Small Scale Version of the In-Tank Precipitation (ITP) Decontaminated Salt Solution (DSS) Stripping Column"

"Program Plan to Evaluate how Tributylphosphate (TBP) affects Benzene Removal from Salt Solution Using Nitrogen Sparging"

"Program Plan to Evaluate Benzene's Solubility in a Salt Solution" 
WSRC-RP-93-928

Page 10 of 23

\section{REFERENCES}

(1) Barnes, M. J. and McGlynn, J. F., "Lab Scale Defoaming Tests on the In-Tank Precipitation Benzene Stripper Column (U) ", SRT-LWP-93-021, March 19, 1993.

(2) Bibler, J. P., "Other Antifoaming Agents for the ITP Stripper", SRT-LWP-93-032, April 13, 1993.

(3) Georgeton, G. K., "Development and Application of a Mathematical Model for the Benzene Stripping Columns in the ITP Process (U)", WSRC-RP-89-1442, December 28, 1989.

(4) Georgeton, G. K., Barnes, M. J., Bibler, J. P., Hobbs, D. T., Walker, D. D., and Langton, C. A., private communication, September, 1992 - May, 1993.

(5) Georgeton, G. K., and Wilson, B. M., "Analysis of ETC Test Results for Benzene Removal with Structured Packing (U) ", WSRC-RP-89-871, September 12, 1989.

(6) Grant, Roger and Grant, Claire, Grant \& Hackh's Chemical Dictionary, 5th Edition, McGraw-Hill, Inc., 1987.

(7) Landon, L. F., "Benzene Striping Late wash Facility - Status Report", SRTC-PTD-92-036, July 31, 1992.

(8) McGlynn, J. F., "Results of the Small Scale Testing on how Late Washing Affects the In Tank Precipitation (ITP) Decontaminated Salt Solution (DSS) Stripping Column (U) ", SRT-LWP-92-090, December 8, 1992.

(9) Perry, Robert H., Green, Don W., Maloney, James O., Perry's Chemical Engineers' Handbook, 6th Edition, McGraw-Hill Book Company, Inc., 1984.

(10) Treybal, Robert E., Mass Transfer Operations, 3rd Edition, Mcgraw-Hill Book Company, Inc., 1987.

(11) Walker, D. D., "Vapor Pressure of Benzene, Methanol, and Isopropanol over Salt Solutions (U)", DPST-88-661, March 28, 1989.

(12) Weast, Robert C., Astle, Melvin J., and Beyer, william H., CRC Handbook of Chemistry and Physics, 64th Edition 19831984, Chemical Rubber Publishing Company, 1985. 
TABLE 1. CONCENTRATION OF A TYPICAL SIMULATED SALT SOLOTION

$\begin{array}{ll}\text { Chemical } & \begin{array}{c}\text { Concentration } \\ \text { (Moles/Liter) }\end{array} \\ \mathrm{NaOH} & 1.30 \\ \mathrm{NaAl}(\mathrm{OH})_{4} & 0.27 \\ \mathrm{NaNO}_{3} & 1.53 \\ \mathrm{NaNO}_{2} & 0.59 \\ \mathrm{Na}_{2} \mathrm{CO}_{3} & 0.14 \\ \mathrm{Na}_{2} \mathrm{SO}_{4} & 0.13 \\ \mathrm{Na}_{2} \mathrm{SiO}_{4} & 0.00 \\ \mathrm{Na}_{2} \mathrm{C}_{2} \mathrm{O}_{4} & 0.013 \\ \mathrm{NaB}\left(\mathrm{C}_{6} \mathrm{H}_{5}\right)_{4} & 0.0051 \text { (sat.) } \\ \mathrm{Na} & 4.83\end{array}$

TABLE 2. CONCENTRATION OF SALT SOIOTION FROM THE EXPERIMENTAL LABORATORY FIITER

$\begin{array}{lcc}\text { Chemical } & \begin{array}{c}\text { Concentration } \\ \text { (Moles/Liter) }\end{array} & \begin{array}{c}\text { Concentration } \\ \text { (ppm) }\end{array} \\ \text { Hydroxide } & 1.701 & 28929 \\ \text { Carbonate } & 0.017 & 1020 \\ \text { Aluminate } & 0.255 & 24228 \\ \text { Aluminum } & >0.265 & >7148 \\ \text { Sodium } & >3.192 & >73393 \\ \text { Silicon } & <0.000 & 13.694 \\ \text { Phosphorous } & <0.000 & <0.9 \\ \text { Phosphate } & <0.001 & <100 \\ \text { Oxalate } & <0.001 & 100 \\ \text { Sulfate } & 0.019 & 1858 \\ \text { Nitrate } & 0.828 & 51318 \\ \text { Nitrite } & 0.211 & 9705 \\ \text { Chloride } & 0.009 & 307 \\ \text { Fluoride } & 0.001 & 23 \\ \text { Tetraphenylborate } & 0.0006 & \mathrm{~N} / \mathrm{A}\end{array}$


WSRC-RP-93-928

Page 12 of 23

FIGURE 1. GRADUATED CYLINDER FOR SALT SOLOTION

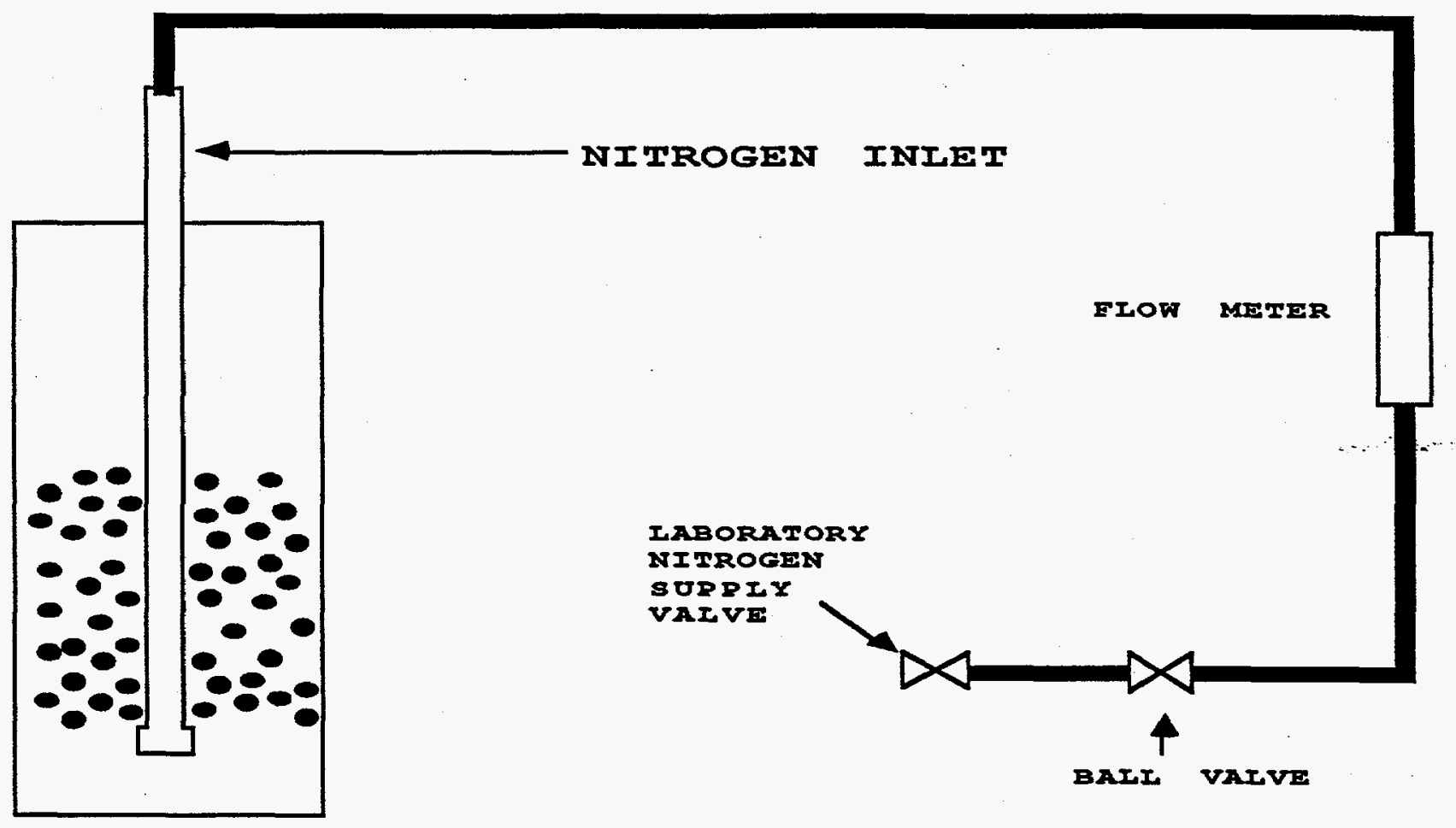


WSRC-RP-93-928

Page 13 of 23

\section{FIGURE 2. SMALL SCALE DECONTAMINATION SALT SOLUTION APPARATOS}

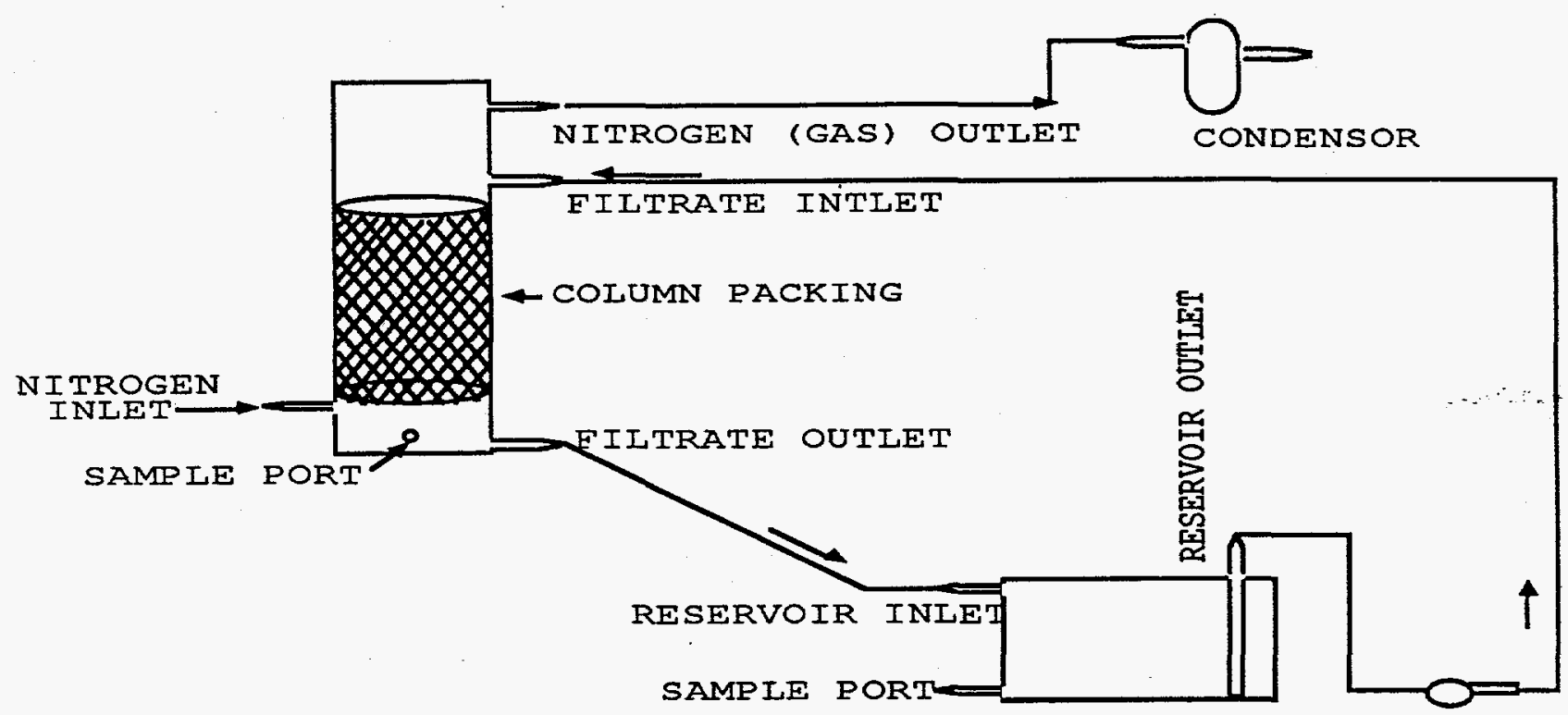

Dimensions and Flow Rates

Column packing height: $40.64 \mathrm{~cm}$

Column packing diameter: $5.08 \mathrm{~cm}$

Nitrogen flow rate:

$1.93 \mathrm{SCFM}=54.65 \mathrm{~L} / \mathrm{min}$ *

Filtrate flow rate:

$1.89 \mathrm{I} / \mathrm{min}^{*}$

Reservoir volume: $680 \mathrm{~mL}$

* These values correspond to the maximum flow rates of 115 GPM filtrate and 440 SCFM nitrogen in the large scale column. 
TABIE 3. NITROGEN AND FILTRATE FLOW RATES AS COMPARED TO THE IN-TANK PRECIPITATION PROCESS

\begin{tabular}{|c|c|c|c|c|}
\hline \multicolumn{5}{|c|}{ Nitrogen Flow Rate } \\
\hline \multicolumn{2}{|c|}{ ITP Column } & Small Scale Column & $\frac{\%}{0}$ & of Maximum \\
\hline 440 & SCEM & $54.65 \mathrm{I} / \mathrm{Min}$ & & $100 \%$ \\
\hline 403 & SCEM & $50.00 \mathrm{~L} / \mathrm{Min}$ & & $91.5 \%$ \\
\hline 382 & SCFM & $47.50 \mathrm{~L} / \mathrm{Min}$ & & $86.9 \%$ \\
\hline 362 & SCFM & $45.00 \mathrm{~L} / \mathrm{Min}$ & & $82.3 \%$ \\
\hline 342 & SCEM & $42.50 \mathrm{~L} / \mathrm{Min}$ & & $77.8 \%$ \\
\hline 322 & SCFM & $40.00 \mathrm{~L} / \mathrm{Min}$ & & $73.2 \%$ \\
\hline 282 & SCEM & $35.00 \mathrm{~L} / \mathrm{Min}$ & & $64.0 \%$ \\
\hline 100 & SCEM & $12.40 \mathrm{~L} / \mathrm{Min}$ & & $22.7 \%$ \\
\hline 50 & SCFM & $6.20 \mathrm{~L} / \mathrm{Min}$ & & $11.4 \%$ \\
\hline \multicolumn{5}{|c|}{ Eiltrate Flow Rate } \\
\hline ITP $\mathrm{Co}$ & Iumn & Small Scale Column & $\frac{q}{z}$ & of Maximum \\
\hline 115 & GPM & $0.5 \mathrm{GPM}$ & & $100 \%$ \\
\hline 92 & GPM & 0.4 GPM & & $80 \%$ \\
\hline 69 & GPM & $0.3 \mathrm{GPM}$ & & $60 \%$ \\
\hline 46 & GPM & 0.2 GPM & & $40 \%$ \\
\hline 23 & GPM & $0.1 \mathrm{GPM}$ & & $20 \%$ \\
\hline
\end{tabular}


FIGORE 3. SMALL SCALE SPARGING APPARATOS FOR BENZENE REMOVAL EFFICIENCY TESTS
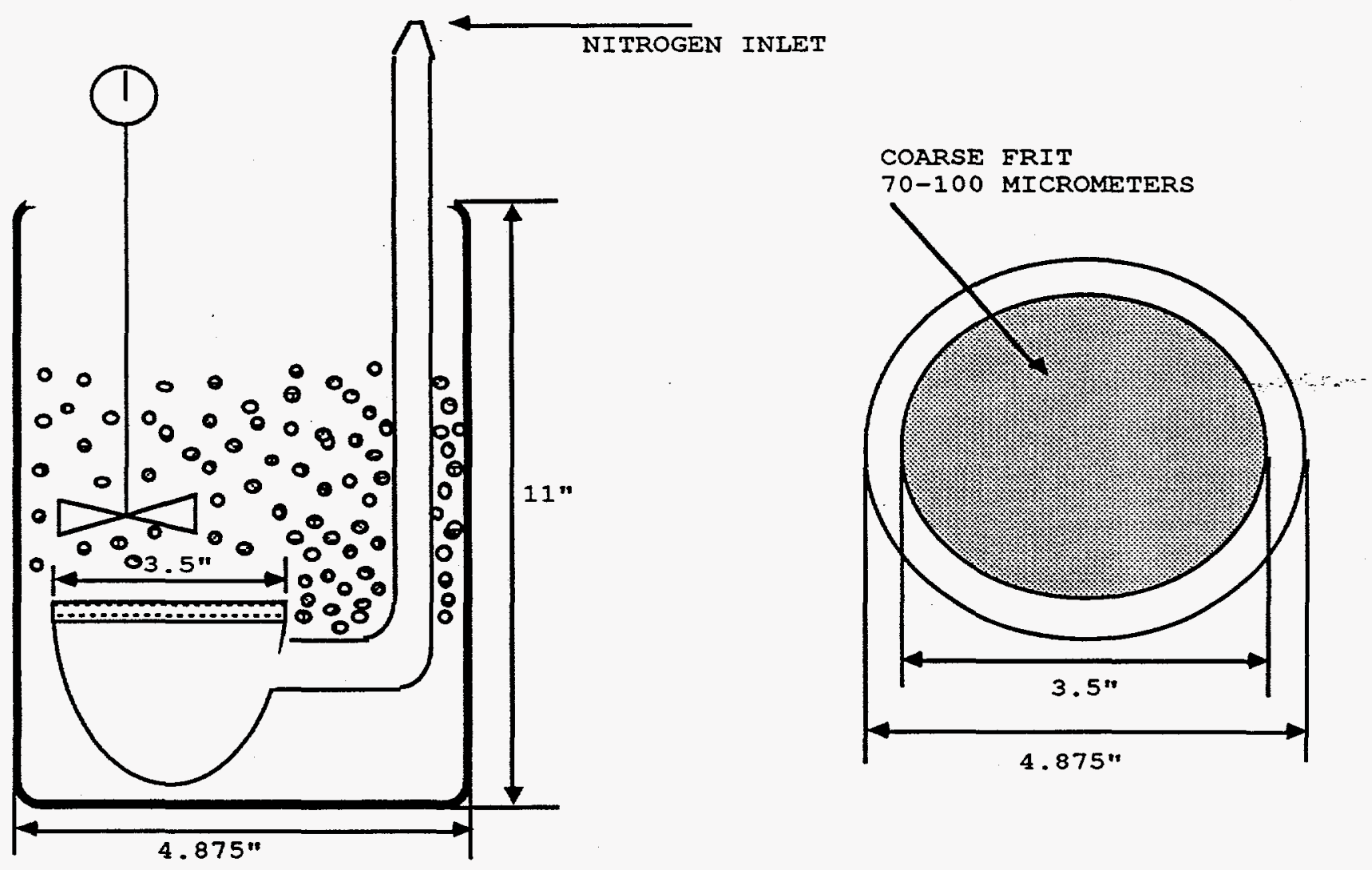
WSRC-RP-93-928

Page 16 of 23

FIGURE 4. SMALI SCALE BENZENE ADDITION APRARATOS

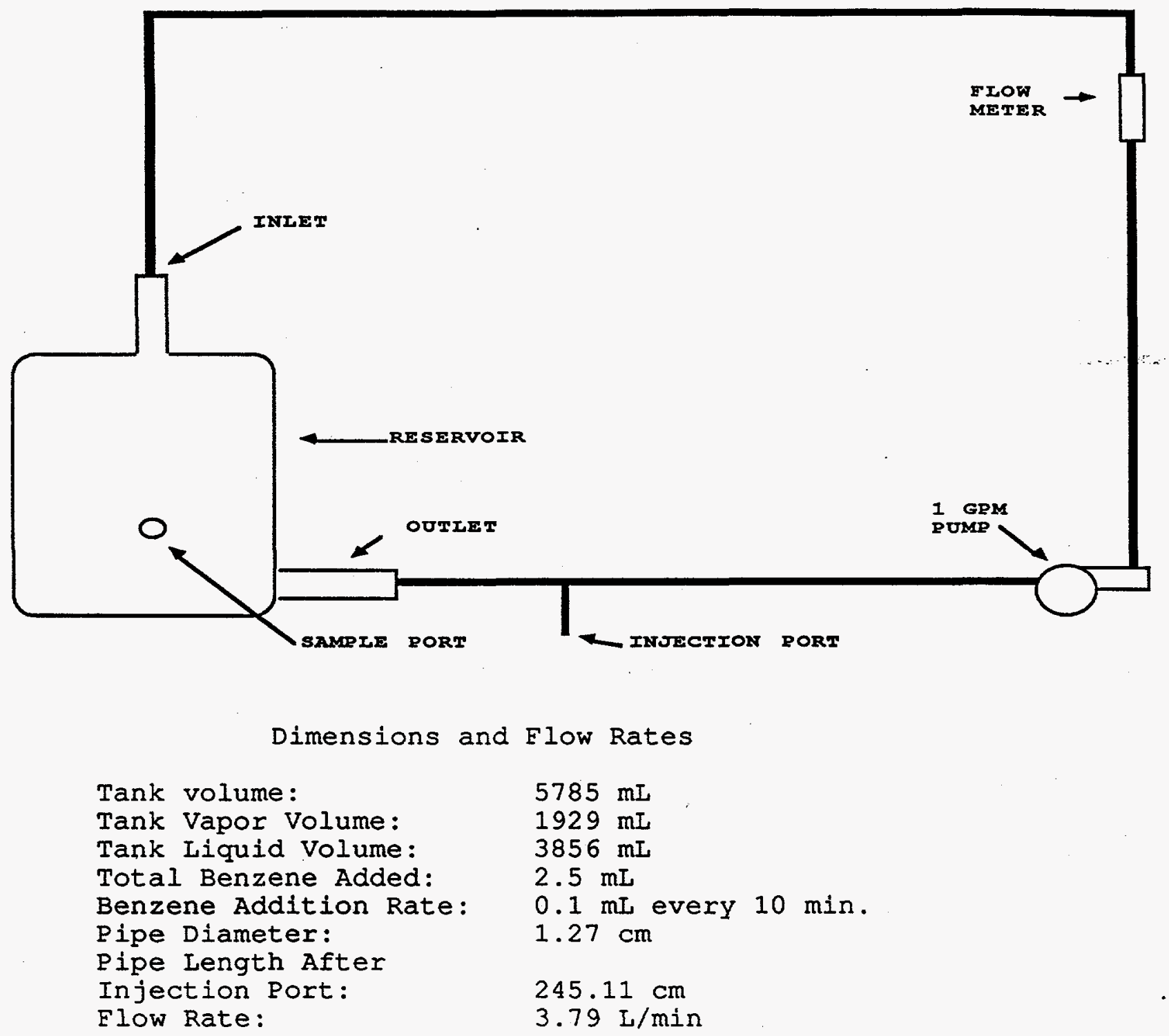


WSRC-RP-93-928

Page 17 of 23

TABLE 4. DEFOAMING AGENTS EFFECT ON FOAM HEIGHT MEASUREMENTS

Defoaming Agent

concentration (pom)

0

25

50

75

100

125

150

175

200

0

25

50

75

100

125

150

175

200

0

35.5

60.0

147.5

183.5
Eeam Height $(\mathrm{cm})$

TBP Gafac ${ }^{\circledR}$ RA-600 Regol ${ }^{\circledR}$ L-62

8.55

2.60

2. 10

2.00

1.50

1.65

13.9

8.8

16.55

10.65

5.0

2.55

2.75

2.8

2.8

2.85

8.5

7.8

11.25

9.6

9.55

8.9

9.0

8.15

Triten $\frac{\AA}{x-100}$ Triten ${ }^{\circledR} \quad x-114$ Surfynol 1045

6.65

7.25

6.95

7.45

7.7

7.8

8.55

7.6

7.4
13.3

12.2

12.2

11.4

13.1

14.1

13.3

13.6

20.1

9.0

7.5

4.7

6.0

3.75

4.05

5.75

4.35

5.65

Dow Corning ${ }^{\circledR}$ Antifoam 544
8.28
8.85
8.75
8.35
8.6 
FIGURE 5. RESOLTS FROM THE GRADUATED CYLINDER
TESTING APPARATUS

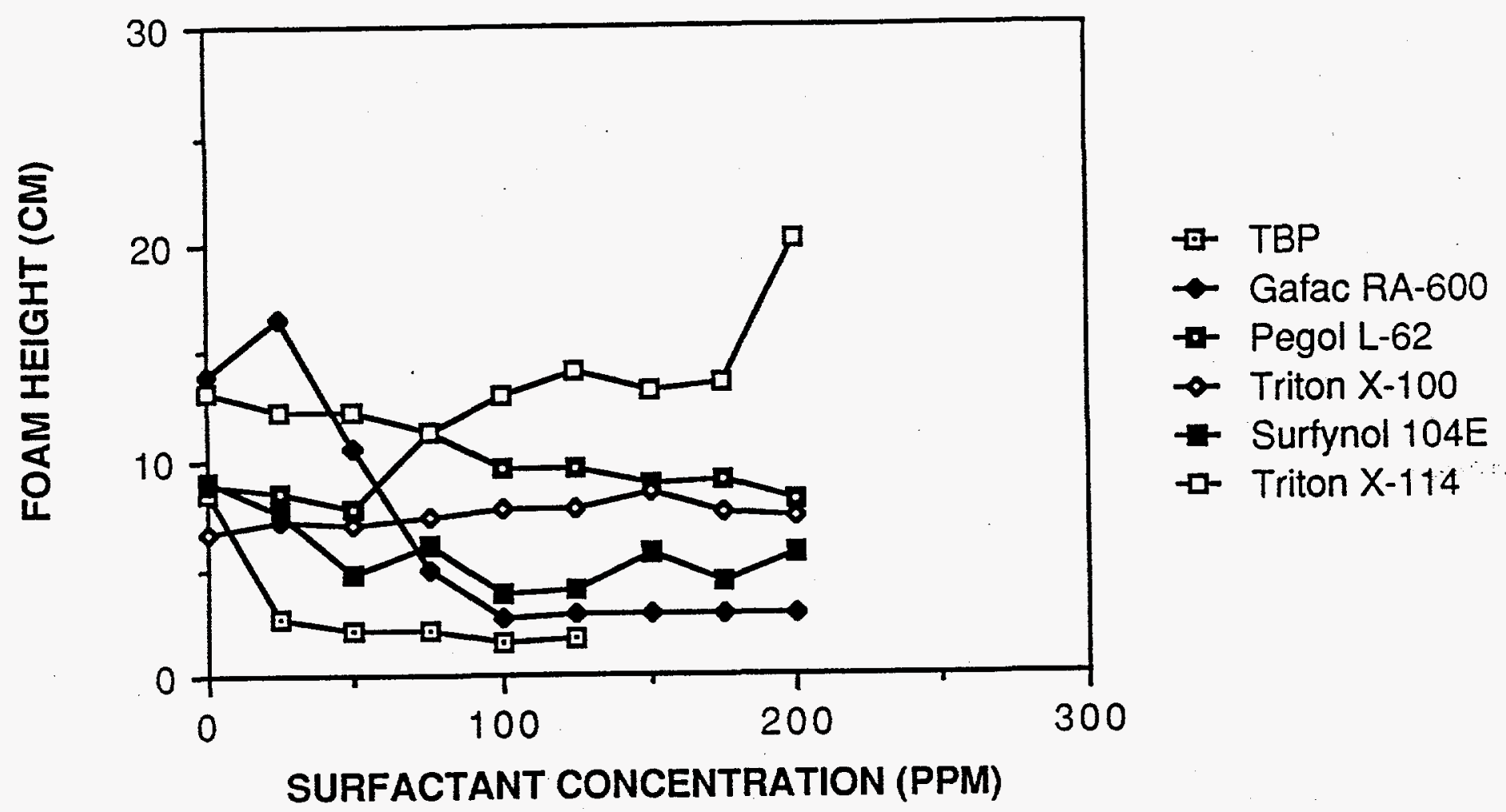

** The Dow Corning ${ }^{\circledR}$ Antifoam 544 was not included on the graph because it was measured in different concentration increments than the other defoaming agents tested, and this defoaming agent was ineffective in inhibiting the foam formation. 
WSRC-RP-93-928

Page 19 of 23

TABLE 5. RESULTS FROM THE SPARGING TEST APPARATUS

TBP
0 ppm

Time

(min)

0

2

4

6

8

10

20

30
Benzene ppm

97.49

13.20

1.14

0.27

0.83

0.92

0.97

0.70
TBP

$150 \mathrm{ppm}$

Benzene

ppm

25.29

2.82

0.92

0.10

0.62

0.79

2.09

1.13
TBP

$300 \mathrm{ppm}$

Benzene ppm

68.94

8.27

0.77

0.42

1.39

0.15

0.93

1.52 
FIGURE 6. GRAPE OF SPARGE TEST RESOLTS

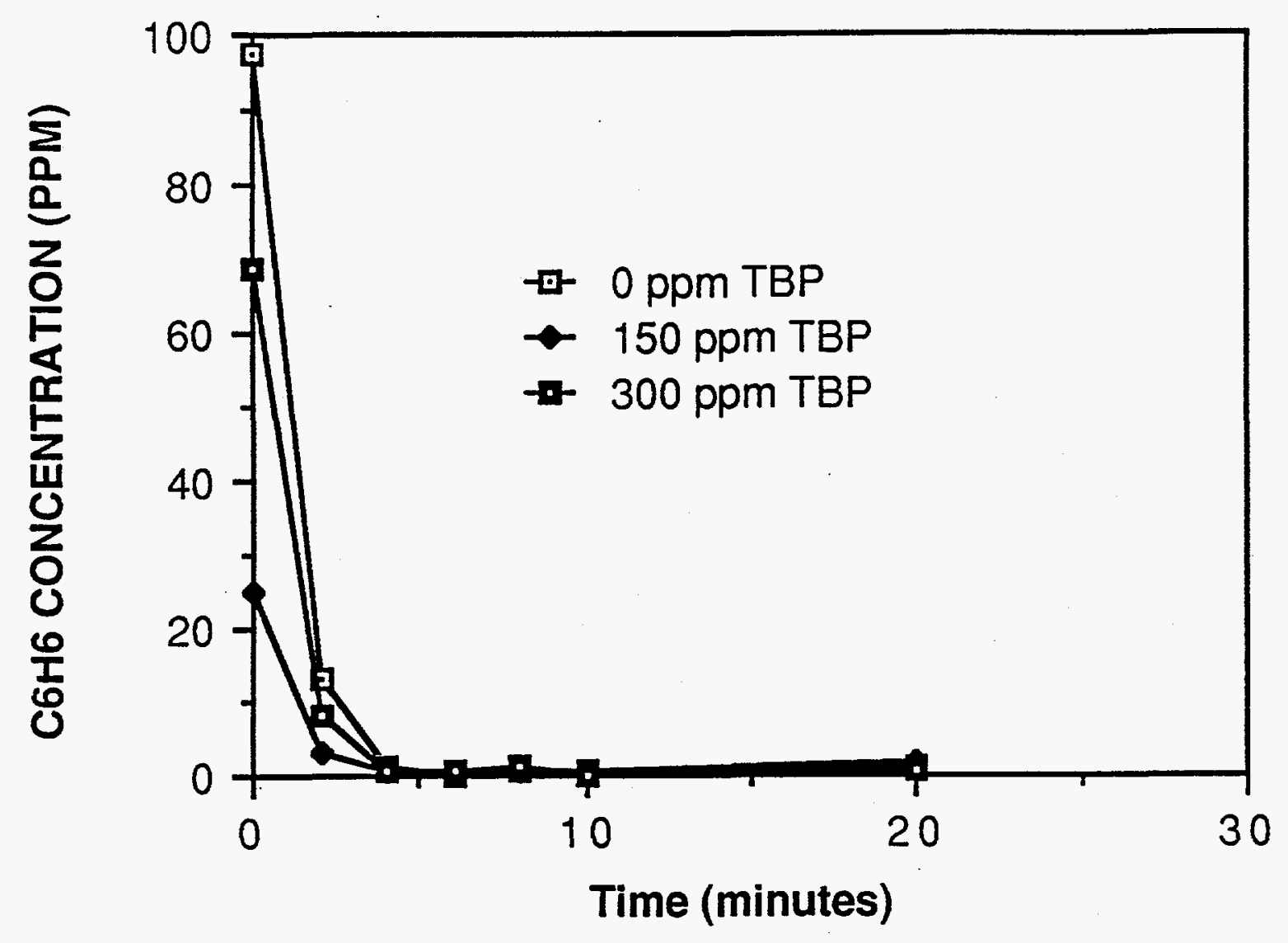


TABLE 6. RESULTS FROM THE BENZENE ADDITION APPARATOS

$\begin{array}{cc}\text { Time (hours) } & \text { Benzene (ppm) } \\ 0 & 0 \\ 1 & 68.7 \\ 2 & 108.5 \\ 3 & 184.7 \\ 4 & 251.8 \\ 5 & 208.2 \\ 6 & 206.3\end{array}$

FIGURE 7 .

GRAPE OF BENZENE ADDITION TEST RESUITS

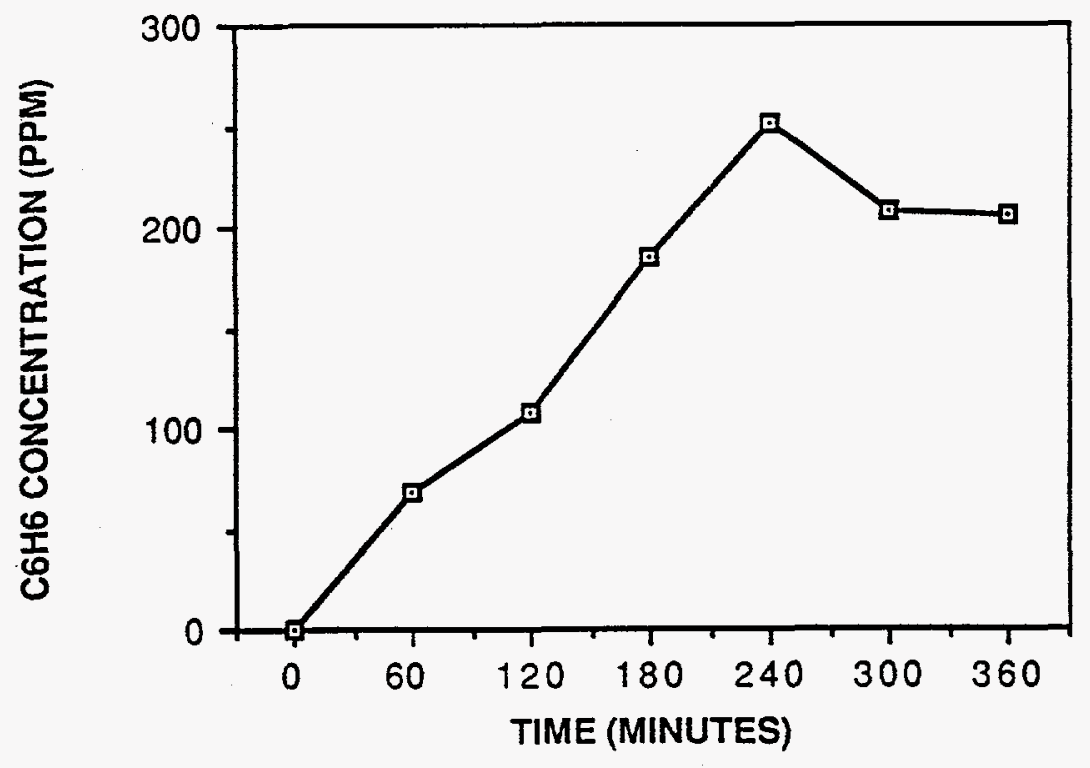


WSRC-RP $-93-928$

Page 22 of 23

\section{EIGURE 8. RESULTS OF WETTING TEST}

\section{OBSERVATIONS :}

Dimensions of the coupon

$\mathrm{L}=50 \mathrm{~mm}$

$\mathrm{W}=19 \mathrm{~mm}$

Coated surface in a salt free environment

Salt solution after 5 minutes

$$
\begin{aligned}
\mathrm{L} & =24 \mathrm{~mm} \\
\mathrm{~W} & =6 \mathrm{~mm}
\end{aligned}
$$

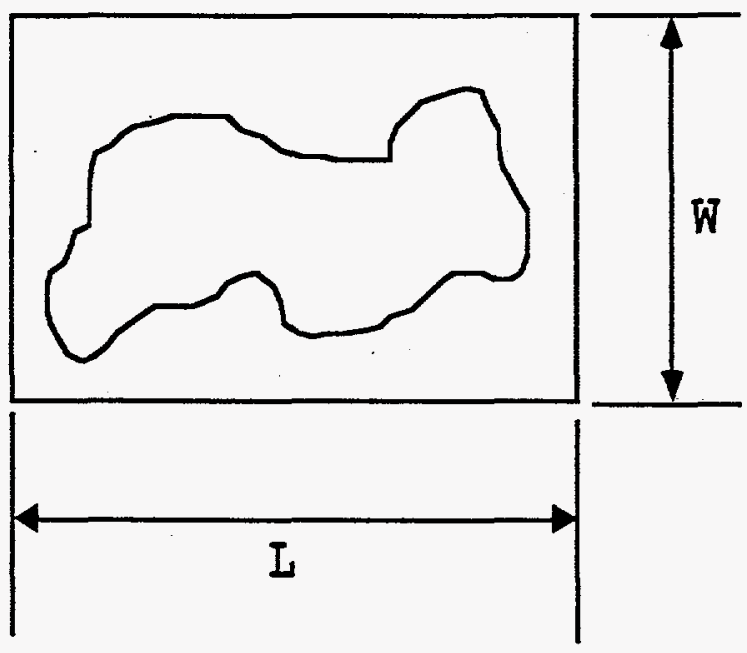

Surfynol $104 \mathrm{E}$ after 5 minutes

$$
\begin{aligned}
\mathrm{L} & =16 \mathrm{~mm} \\
\mathrm{~W} & =7 \mathrm{~mm}
\end{aligned}
$$

Tributylphosphate after 5 minutes

$$
\begin{aligned}
& \mathrm{L}=41 \mathrm{~mm} \\
& \mathrm{~W}-10 \mathrm{~mm}
\end{aligned}
$$

Coated surface after the coupon was covered with salt solution

Tributylphosphate after 5 minutes

$$
\begin{aligned}
& \mathrm{L}=8 \mathrm{~mm} \\
& \mathrm{~W}=8 \mathrm{~mm}
\end{aligned}
$$

Surfynol $104 \mathrm{E}$ after 5 minutes

$$
\begin{aligned}
\mathrm{L} & =12 \mathrm{~mm} \\
\mathrm{~W} & =7 \mathrm{~mm}
\end{aligned}
$$




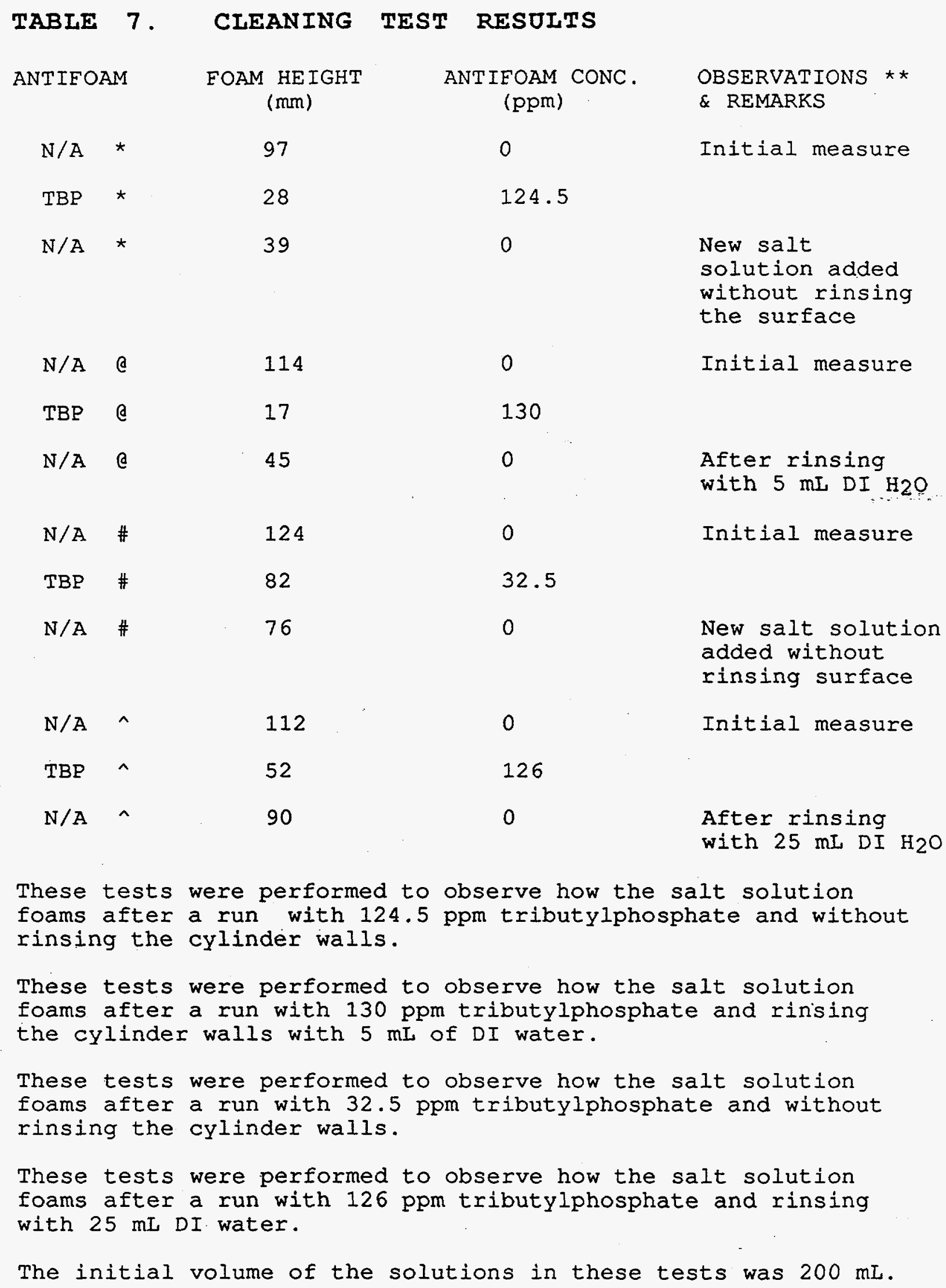

